\title{
The Virtual Power Plant - A Review Of Business Models
}

\author{
Edyta Ropuszyńska-Surma ${ }^{1}$, Magdalena Węglarz ${ }^{1, *}$ \\ ${ }^{1}$ Wroclaw University of Science and Technology, Faculty of Computer Science and Management, \\ Wyb. Wyspianskiego 27, 50-370 Wroclaw, Poland
}

\begin{abstract}
The aim of the article is to present a critical comparison of different business models of Virtual Power Plant and pointing out both the common and the unique features for each model. Therefore, the American, German, Finnish, Danish and Australian VPP's business models are described in the article. The VPP is an IT structure which integrates different types of distributed energy sources, flexible consumers and energy storage with each other and with other market segments in real time through a smart grid. The VPP gives positive effects on electricity grid like ensuring energy security, improving grid stability and reliability, optimization of energy resources use, lowering the load - demand response, regulation of frequency, using operational reserves, management of peak demand. The business model is perceived as a method of increasing and exploitation of company's resources for preparing new products or services for customers in order to obtain added value (expanding the competition advantage or increasing profitability). A potential VPP's business model in Polish conditions was proposed in case of two different types of customers.
\end{abstract}

\section{Introduction}

The development of Polish Renewable Energy Sources (RES) sector, especially the development of Distributed Energy Resources, should be stimulated by two factors: (1) the complex amendment of the RES Act and (2) the planned introduction of, so called, 'power market'. The former was introduced in Poland on $1^{\text {st }}$ July 2016, and its effects are new kinds of entrepreneurship such as clusters, energy cooperatives, and the auction system dedicated to the RES installations.

One of the most reliable as well as the most efficient way of ensuring the efficiency, the stability, and the competitiveness of distributed generation is using the Virtual Power Plant (VPP) technology. The concept of the VPP became possible due to the development of information and telecommunication technologies (IT) in recent years. A VPP is a system that integrates several types of power sources in order to give a reliable overall power supply. A VPP consists of a central IT control system and distributed energy resources (often RES like solar, wind, hydropower, and biomass units) as well as flexible power consumers and batteries. Energy producers offer their free capacities to the VPPs. A VPP purchases the capacity flexibilities from energy producers, manages the power plant production based on

\footnotetext{
* Corresponding author: magdalena.weglarz@pwr.edu.pl
} 
real-time sales demands, and sells the electricity produced on multiple markets at the same time - on a Power Exchange (PEx), on the balancing energy market, and directly to end-users. All these lead to higher margins for small-scale power plants without the additional costs of sales and balancing energy.

By successfully combining business and technology innovations, the VPP has developed a pioneering business concept based on the powerful synergies between the existing energy market segments. The business model (BM) concepts gained popularity recently, partly due to the business interests and partly due to the growth and globalization [1]. It could be defined in terms of the firm's value proposition and market segments, the structure of the value chain required for realizing the value proposition, the way of value capture that the firm develops, and how these elements are connected together in an architecture [2]. In section 2 a short review of different definitions of BMs is presented and a list of the essential components is given due to the overview of BMs made by Wirtz et.al [3] The core components are market offerings (value proposition - prosumer benefits) and resources. The important components, indicated by $50 \%$ of researchers, are strategy, network (infrastructure and asset management with advanced smart technologies), customers and revenue streams (customized revenue model for prosumers).

Therefore, the American, German, Finnish, Danish and Australian VPPs business models will be described in the article. The main aim of this paper is a critical comparison of these BMs and pointing out both the common and the unique features for each country. Based on these examples, potential VPP business model in Polish conditions will be presented.

\section{The development of the business model concept}

Founded by Bellman, Clark, Malcolm, Craft and Ricciardi, the term of BM was first used in 1957. The BM gained greater importance with evolving technological development over time and the formation of electronic business. At that time, the BM became some kind of presentation of the company organization for having contribution to the success of management in the decision-making process. The importance of BMs in practice have grown in the last few years, in particular as they are connected with ensuring and growing competitive advantage [3].

\subsection{Analysis of business model definitions}

In general, there is no one common definition of BM. Definitions of BMs differ depending on three basic perspectives of technology, organization and strategy. Until 2002, the most popular were technologically-oriented BMs. The importance of strategy-oriented concept has increased after 2002, however only after 2005 the concept of organisationoriented $\mathrm{BM}$ was formulated.

At the beginning of the technology-oriented concept development, the authors perceived the $\mathrm{BM}$ as a small part of a company, but later they see the BM increasingly as a representation of the company. A special importance is put on the architecture of flow of products, services, information, cash and benefits generated by individual entities included in the model $[4,5]$. The flow of the above- mentioned components is defined by the relation between customers, clients, partners and suppliers. The BM is perceived as a method of increasing and exploitation of company's resources for preparing new products or services for customers in order to obtain added value (expanding the competition advantage or increasing profitability) [6]. The model is a set of actions that should be taken by company, the relation between them, and the entities responsible for the different activities [7].

From the organization-oriented perspective a business model is seen as a tool for the abstraction of the entire company as a kind of a system that solves the key company problems 
such as identifying the customer, recognizing their needs, delivering satisfaction, and changing the value into cash [8]. The concept focuses on the cause and effect relationships and on the reasons of value creation. The fundamental elements of the model are: customer segments, value proposition, channels, customer relations, revenue streams, cost structure and key resources, activities and partners [9].

The authors of the strategy orientation see the BM as a strongly abstract tool to show a picture of the company's competitive situation. The key concept is that a BM is a direct result of a strategy, but is not a strategy. Besides, the strategy BM is defined by strategic resources, relation with buyers and value chain [10]. BM can be seen as a story that explains how the company operates and what is especially relevant for success [11]. In other opinion the model is perceived as a list of functions such as formulating a competitive strategy and value chain structure, estimating the cost structure and profit potential, describing the position of the company [12]. Moreover, the model could be described by the manner in which the company delivers value to customers, encourages customers to pay for value, and converts those payments into profit [13].

In recent years an increasing holistic approach to defining BM can be observed. Summarizing it can be stated according to Wirtz et al. [3] that BM "is a simplified and aggregated representation of the relevant activities of a company. It describes how marketable information, products and/or services are generated by means of a company's value-added component. In addition to the architecture of value creation, strategic as well as customer and market components are taken into consideration, in order to achieve the superordinate goal of generating, or rather, securing the competitive advantage."

\subsection{Components of business model}

Shafer et al. in [14] classified twelve different definitions of BMs in established publications during 1998-2002, which together produced a list of forty-two different BM components. Wirtz et al. in [3] provided an integrated and comprehensive approach regarding the completeness of the BM components. The BM represents a conceptual framework in order to organize the value creation of a company and to guarantee profitability. As noted above, internal as well as external factors must be considered to present a holistic picture. In addition to the general implications of the corporate strategy, customers and the market (external factors) on the one hand, and the conditions of service provision/value creation (internal factors) on the other hand, must be taken into account.

These considerations resulted in a business model consisting of nine essential components: (1) strategy, (2) resources, (3) network, (4) customer, (5) value proposition, (6) revenue, (7) service provision, (8) procurement and (9) finances. The core of BM is "value proposition" because the consumers and other stockholders pay for it. They do not pay only for the product core but for other added value e.g.: cleaner air, human rights, fulfil services, product design. Every BM should ensure the revenue. Thus, the customer segments, customer relations and distribution channels are described. It allows planning the service provision, procurement, marketing and other actions addressed to clients. The revenue totals forecast revenue coming from service provision. The business can create and provide the value only if it possess resources (technology, capital, human, natural, knowledge) and cooperate with other entities (business partners). The usage of the resources and cooperation with business partners creates costs, which should be forecasted in business model. On the strategical level aims of business should be defined, which allows to offer a coherent concept of business and determines the directions of activities at the operation level. Between all the elements there are cause-and-effect relations, e.g. the cost structure is not a spontaneous element of the BM, but it is a derivative of the method of providing value to clients, which consists of activities or resources used to create them as well as established relations with business partners. 


\section{Virtual Power Plant}

The VPP is quite a new concept. Its idea was created a few years ago and has a some advantages working in its favor. The main concept is based on a centralized control structure which connects, controls and visualizes the work of distributed generators. Combined heat and power generators (CHP), fuel cells (FC), photovoltaics (PV), heat pumps (HP), solar collectors and any other sources of power and heat might be aggregated and cooperate in the local area. The VPP has no one definition and different authors emphasize significant features for analyzed situations.

In this paper, the VPP is treated as a part of a virtual organization (VO). Therefore, the virtual organization is a starting point in this considerations. According to K. Jacobsen [15], the first person who used the term 'Virtual Organization' was A. Mowshowitz in 1986. Mowshowitz's [16] approach focuses on different dimensions of virtuality such as virtual memory, virtual reality, virtual classrooms, virtual teams and virtual offices. The ITC technologies are necessary to discuss about the VOs. In 1990's the concept of VOs was more frequently described in the literature as organizational phenomena and technological and organizational innovation. This concept was becoming more popular in the theory of organization and management. In accordance with the system theory of organization and management, the scientists distinguished two approaches to the VOs. The first is the process approach which emphasized actions and organizational behaviours with key functions like coordination, acting, and other typical management functions supported by the ITC. Therefore, the VOs are treated as dynamic management tools [16, 17]. The second is the structural approach which focuses on cooperation between independent entities. This cooperation could take different forms, e.g.: networks, alliance, coalition, franchising contract, outsourcing. On the one hand, it is seen that the VOs aggregate in the dynamic structure of independent entities (e.g. companies, social organizations, natural persons) and the legal agreements are required in this situation. On the other hand, they improve the effectiveness and efficiency of organizations by the process management. Generally, the VO is a network integrating entities into one virtual managed organization [18-21]. A similar approach is presented by Zimniewicz [22] who says that the VO involves the inclusion of all or just some people from various organizations to work together on the market. An important feature of the $\mathrm{VO}$ is using integration and/or gathering in one virtual structure, cooperating as well as managing by means of the IT [23]. Elaborating of these different concepts of the VO, characteristics such as networking basing on trust, cooperation, dynamic and open structure (the entities have open entrance and exit), active usage of IT software and ITC can be distinguished. A VO is not related to one place or time and it may increase the number of participants located in different places or characterized by mobility.

\subsection{Concept of VPP}

Base on the VO concept, the VPP was established in energy sector. According to P. Asmus, the VPPs are ,software systems to remotely and automatically dispatch and optimize generation or demand side or storage resources in a single, secure Web-connected system. In short, VPPs represent an "Internet of energy" tapping existing grid networks to tailor electricity supply and demand services for a customer, maximizing value for both end-user and distribution utility through software innovations" [24]. Kumagai in [25] stresses the innovative ITC technologies used in the energy sector, e.g.: the smart-grid infrastructure, disparate energy resources. In this concept, the VPPs are in opposition to the conventional energy sector using fossil fuels. He stated that almost every energy source can offer energy to VPP and "contribute to a virtual power, not (VPN) plant's capacity" [25]. But the VPP is complement to large power plants. "A VPP is a flexible representation of a portfolio of DER 
that can be used to make contracts in the wholesale market and to offer services to the system operator." [26]. 'Distributed energy resources' (DER) are defined in IEEE 1547.3 to "include both generation and energy storage technologies". It is also important to define the term 'distributed': "distributed generation is an electric power source connected directly to the distribution network or on the customer site of the meter" [27].

Heading the VPP is a computer system controlled by the Distribution System Operator (DSO). This could be organized on the basis of an artificial neural network. In fact, a VPP could be supported by any household which has as little as $1 \mathrm{~kW}$ capacity in a generator such a PV, FC, CHP etc. In VPP irrespective of how much generation capacity is installed in a single building, the most important feature is connecting all the sources together and running them so as to obtain a state of self-balance in the most efficiency way [28].

The VPPs could be classified according to such criteria as the kind of efficiency and the type of regulation model in energy sector. Taking efficiency into consideration there are two types of VPP [26,27]: a commercial and technical. Offering the aggregated profile of the DER units to the transmission system requires both commercial and technical actors [26]. According to the second criteria, the VPP could be divided up into [24]:

- the European model focuses mainly on managing supply side which consists of distributed and small RES units. The coordination of their work results in a coherent aggregated energy system on the local level. The system could be enriched by the participation of energy coming from wholesale market and the management of energy usage in commercial consumers

- the American model - the main function of the VPP is a flexible response on demand in real-time. The utility of demand response (DR) and critical-peak pricing programs are significant. The VPPs are like traditional power plants which offer peak capacity, energy or grid reliability regulation services.

These different models require different types of management system of the VPP, its business model and functions of IT system.

\subsection{Reasons and conditions of VPP}

In accordance with the system theory, the VPP belongs to four systems and it is shaped by one. These systems are: technical, legal, economic and social. The changes, including technical and social innovations, are the key reasons for establishing and developing the VPP. The most significant changes belonging to such systems are (fig. 1):

- technical systems - here the changes are linked to: information and telecommunication technologies (ITC), Smart Grids (SG) and smart metering (SM), RES technologies, storages of RES (e.g. electricity container and electric cars), ensuring energy security,

- legal system with new regulations like the following: focus on the support system of RES installations, limits of greenhouse gases emissions, the priority for the RES, legal regulation of prosumer;

- economic system with such elements like: liberalization of energy sector, including electricity whole markets and establishment of the PEx and the power markets, economic tools belonging to demand side management (DSM) and demand response, mainly tariff system, high energy prices, economic trend to regionalization of energy market and creating local energy market connected with autonomous energy areas ("energy islands") base on local RES, establishing prosumers, economic cost connected with blackouts; 
Table 1. Comparison of business models.

\begin{tabular}{|c|c|c|c|c|c|c|}
\hline Localization & Strategy & Resources & Network & Customer & Value proposition & Revenue \\
\hline $\begin{array}{l}\text { Ameland } \\
\text { Island } \\
\text { (Denmark) }\end{array}$ & $\begin{array}{l}\text { To be carbon neutral } \\
\text { by } 2020\end{array}$ & $\begin{array}{l}6 \mathrm{MW} \\
\text { solar PV }+45 \text { fuel cell-based m-CHP } \\
\text { units } \\
\text { major financial contributor: Wadden } \\
\text { Fund, the Municipality of Ameland, } \\
\text { Republic Power, Sustainable } \\
\text { Ameland, utility and energy } \\
\text { companies GasTerra and Liander } \\
\end{array}$ & $\begin{array}{l}\text { - Supplier: CFCL - } 45 \\
\text { BlueGen units } \\
\text { - Gas supplier }\end{array}$ & $\begin{array}{l}\text { - } \text { residential } \\
\text { - distribution } \\
\text { energy } \\
\text { companies }\end{array}$ & $\begin{array}{l}\text { - lower energy costs } \\
\text { - modulation up or down to meet } \\
\text { peak loads and balance } \\
\text { intermittent power from wind } \\
\text { or solar by using fuel cells }\end{array}$ & $\begin{array}{l}\text { - the participants can } \\
\text { take over the } \\
\text { BlueGEN units for } \\
\text { an administrative } \\
\text { fee }\end{array}$ \\
\hline $\begin{array}{l}\text { North Rhine- } \\
\text { Westphalia } \\
\text { (Germany) }\end{array}$ & $\begin{array}{l}\text { To increase the CHP } \\
\text { share of electricity } \\
\text { generation to more } \\
\text { than } 25 \% \text {. }\end{array}$ & $\begin{array}{l}25 \text { units } 1.5 \mathrm{~kW} \text { BlueGen solid oxide } \\
\text { fuel cell mCHP } \\
\text { Financial support from the state of } \\
\text { North Rhine-Westphalia of } € 250 \\
\text { million }\end{array}$ & $\begin{array}{l}\text { - Managed by municipal } \\
\text { utility Trianel } \\
\text { - } 15 \text { municipal utilities } \\
\text { - Supplier: Sanevo Blue } \\
\text { Energy GmbH \& CO. } \\
\text { - Gas supplier }\end{array}$ & $\begin{array}{l}\text { - municipal } \\
\text { customer } \\
\text { centres and } \\
\text { selected } \\
\text { customers }\end{array}$ & $\begin{array}{l}\text { - to establish highly efficient } \\
\text { mini and micro CHP systems } \\
\text { on the market under the name } \\
\text { EnergieBlock }\end{array}$ & No data \\
\hline $\begin{array}{l}\text { "Next Poll" } \\
\text { VPP } \\
\text { (Germany, } \\
\text { Austria, } \\
\text { Belgium)- } \\
\text { Center in } \\
\text { Cologne }\end{array}$ & $\begin{array}{l}\text { To increase share in } \\
\text { RES in electricity } \\
\text { generation }\end{array}$ & $\begin{array}{l}4583 \text { MW (combined capacity) } \\
\text { installations of RES: biogas, wind } \\
\text { and PV with commercial and } \\
\text { industrial power consumers, power } \\
\text { storage systems } \\
5477 \text { units (IV 2018) } \\
\text { IT software NEMOCS system }\end{array}$ & $\begin{array}{l}\text { - Operator: Next } \\
\text { Kraftwerke GmbH }\end{array}$ & $\begin{array}{l}\text { - commercial } \\
\text { and industrial } \\
\text { consumers, } \\
\text { - energy } \\
\text { storages }\end{array}$ & $\begin{array}{l}\text { - higher profits } \\
\text { - balancing energy stabilizes the } \\
\text { electricity networks } \\
\text { - stable grid for everyone }\end{array}$ & $\begin{array}{l}\text { - } 283 \text { mio Euro } \\
\text { (2016) coming } \\
\text { from: participation } \\
\text { of the consumer in } \\
\text { the platform of } \\
\text { energy trading, fee } \\
\text { of energy portfolio } \\
\text { and balancing } \\
\text { group }\end{array}$ \\
\hline $\begin{array}{l}\text { Adelaide, } \\
\text { South } \\
\text { Australia }\end{array}$ & $\begin{array}{l}\text { To ensure energy } \\
\text { security }\end{array}$ & $\begin{array}{l}5 \mathrm{MW} \\
1,000 \text { solar PV and Energy Storage } \\
\text { Systems (Tesla Powerwall home } \\
\text { battery) }\end{array}$ & $\begin{array}{l}\text { - Funding partner } \\
\text { Australian Renewable } \\
\text { Energy Agency, } \\
\text { - AGL } \\
\text { - Supplier: Sonnen and } \\
\text { Tesla } \\
\end{array}$ & - residential & - to cut electricity costs & $\begin{array}{l}\text { ancillary services } \\
\text { the company sells } \\
\text { to the grid operator } \\
\text { - lump sum or } \\
\text { payment for in } \\
\text { installment } \\
\end{array}$ \\
\hline $\begin{array}{l}\text { Vermont, } \\
\text { New England } \\
\text { (USA) }\end{array}$ & $\begin{array}{l}\text { To provide grid } \\
\text { services, including } \\
\text { provision of dynamic } \\
\text { capacity to meet } \\
\text { shortfalls in supply } \\
\text { and to add grid } \\
\text { stability } \\
\end{array}$ & $\begin{array}{l}\text { 12.8 MW } \\
\text { solar PV } \\
2,000 \text { residentials Powerwall and } \\
\text { commercial and industrial (C\&I) } \\
\text { Powerpack systems }\end{array}$ & $\begin{array}{l}\text { - Green Mountain } \\
\text { Power } \\
\text { - Supplier: Tesla }\end{array}$ & $\begin{array}{l}\text { - residential } \\
\quad \text { commercial } \\
\text { and industrial }\end{array}$ & $\begin{array}{l}\text { - lowering utility costs for rate } \\
\text { payers, } \\
\text { - the customer makes some of } \\
\text { the batteries' capacity available } \\
\text { to the utility to use for grid- } \\
\text { balancing or peak demand } \\
\text { reduction }\end{array}$ & $\begin{array}{l}\text { - fee for using } \\
\text { batteries for } 10 \\
\text { years } \\
\text { - revenue from using } \\
\text { batteries in trading } \\
\text { their power in } \\
\text { wholesale market }\end{array}$ \\
\hline
\end{tabular}




\begin{tabular}{|c|c|c|c|c|c|c|}
\hline $\begin{array}{l}\text { Brooklyn and } \\
\text { Queens, New } \\
\text { York, USA }\end{array}$ & $\begin{array}{l}\text { To improve grid } \\
\text { resiliency, reliability } \\
\text { and sustainability }\end{array}$ & $\begin{array}{l}1.8 \text { megawatts in leased solar PV } \\
\text { with an equivalent capacity of } \\
\text { batteries } \\
300 \text { homes } \\
\text { Supervisory control and data } \\
\text { acquisition (SCADA) }\end{array}$ & $\begin{array}{l}\text { - Con Edison, } \\
\text { - SunPower } \\
\text { - Sunverge }\end{array}$ & - residential & $\begin{array}{l}\text { - to reduce the homeowners' } \\
\text { monthly electricity costs, } \\
\text { - to provide homeowners with a } \\
\text { backup system in case of an } \\
\text { outage }\end{array}$ & $\begin{array}{l}\text { - leasing of } \\
\text { SunPower solar } \\
\text { systems }\end{array}$ \\
\hline Finland & $\begin{array}{l}\text { VPP reduces overall } \\
\text { Finnish carbon } \\
\text { footprint by } 0,5 \%\end{array}$ & $\begin{array}{l}\text { Load is } 32 \mathrm{MW} \text { : } \\
-22 \mathrm{MW} \text { - microgrids } \\
-10 \mathrm{MW} \text { - energy storages }\end{array}$ & $\begin{array}{l}\text { - Siemens } \\
\text { - Finnish goverment }\end{array}$ & $\begin{array}{l}\text { commercial } \\
\text { and industrial } \\
\text { (min. } 0,1 \mathrm{MW} \\
\text { / building } \\
\text { owner) } \\
\end{array}$ & $\begin{array}{l}\text { - to create a combined and open } \\
\text { market place for energy sector. } \\
\text { - to speed up the usage of } \\
\text { renewable energy sources with } \\
\text { sustainable manner. }\end{array}$ & No data \\
\hline
\end{tabular}

Table 2. A proposition of VPP's business model for Poland.

\begin{tabular}{|c|c|c|c|c|}
\hline Resources & Network & Customer & Value proposition & Revenue \\
\hline \multirow{3}{*}{$\begin{array}{l}\text { PV } \\
\text { Hydro plant } \\
\text { Energy storage system } \\
\text { IT platform } \\
\text { Smart metering }\end{array}$} & \multirow{3}{*}{$\begin{array}{l}\text { Key partners: } \\
-\quad \text { ISO } \\
- \text { TSO, DSO and retail utility } \\
-\quad \text { Telecommunication company } \\
\text { Key activities: } \\
-\quad \text { Energy schedules } \\
- \text { Monitoring } \\
-\quad \text { Optimization of energy demand } \\
\text { and costs }\end{array}$} & $\begin{array}{l}\text { segment: A large buyer, buying energy under a } \\
\text { long-term bilateral contract }\end{array}$ & \multirow{3}{*}{$\begin{array}{l}- \text { Supply of energy in the case of } \\
\text { a shortage } \\
\text { - Low purchase price of energy } \\
- \text { Security of energy supply } \\
-\quad \text { Convenience and speed of } \\
\text { service } \\
-\quad \text { Availability of a dedicated } 24 \mathrm{~h} \\
\text { customer manager } \\
-\quad \text { Savings due to the consultation } \\
\text { about energy management }\end{array}$} & \multirow{3}{*}{$\begin{array}{l}\text { - Subscription fee } \\
\text { linked to } e . g .: \\
\text { scheduling } \\
- \text { Energy selling } \\
- \text { Ensuring energy } \\
\text { safety }\end{array}$} \\
\hline & & $\begin{array}{l}\text { relationships } \\
- \text { A dedicated customer relationship manager } \\
- \text { Free software } \\
- \text { Automated service }\end{array}$ & & \\
\hline & & $\begin{array}{l}\text { channels } \\
\text { - Direct telephone and Internet contact } \\
\text { - Contact through the customer's panel }\end{array}$ & & \\
\hline \multirow{3}{*}{$\begin{array}{l}\text { PV } \\
\text { Hydro plant } \\
\text { Energy storage system } \\
\text { IT platform } \\
\text { Smart metering } \\
\text { Price forecast and loan } \\
\text { schedule } \\
\text { Knowledge about } \\
\text { energy market and its } \\
\text { rules }\end{array}$} & \multirow{3}{*}{$\begin{array}{l}\text { Key partners: } \\
\text { - ISO } \\
\text { - TSO, DSO and retail utility } \\
\text { - Telecommunication company } \\
\text { Key activities: } \\
\text { - Energy schedules } \\
\text { - } \text { Forecasting (weather, generation, } \\
\quad \text { consumption) } \\
-\quad \text { Monitoring } \\
-\quad \text { Optimization of energy } \\
\quad \text { production and price }\end{array}$} & $\begin{array}{l}\text { segment: Owner of micro-installation (small } \\
\text { energy producer) }\end{array}$ & \multirow{3}{*}{$\begin{array}{l}\text { - Higher revenue from sales of } \\
\text { energy } \\
\text { - Convenience and ease of use } \\
\text { - Lower risk of selling energy } \\
\text { - Negawatts }\end{array}$} & \multirow{3}{*}{$\begin{aligned} \text { - } & \text { Bilateral agreement } \\
\text { - } & \text { Subscription fee } \\
& \text { linked to e.g. } \\
& \text { scheduling, services } \\
& \text { of dedicated manager } \\
- & \text { Ensuring energy } \\
& \text { safety }\end{aligned}$} \\
\hline & & $\begin{array}{l}\text { relationships } \\
-\quad \text { A dedicated customer relationship manager } \\
- \text { Free software } \\
- \text { Automated service } \\
- \text { B2B relations } \\
\end{array}$ & & \\
\hline & & $\begin{array}{l}\text { channels } \\
\text { - Direct telephone and Internet contact } \\
\text { - Contact through the customer's panel }\end{array}$ & & \\
\hline
\end{tabular}


- social system connected with changing behaviors of energy consumers, higher ecological awareness of society, the establishment of network cooperation, based on local energy sources such as energy cooperatives, energy clusters, the need to keep energy security.

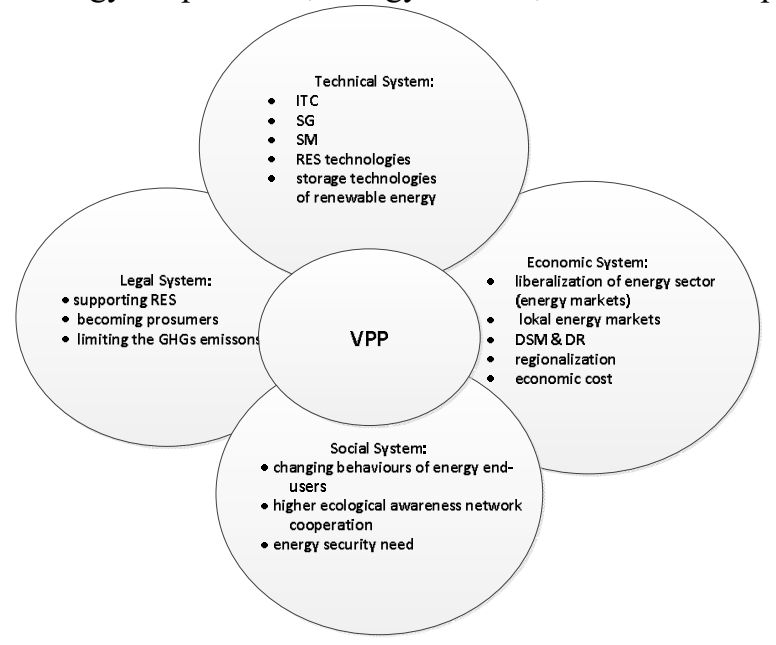

Fig. 1. The reasons and conditions of VPP.

There are links between elements belonging to different systems. It is difficult to divided some of them. They should be taken into consideration together, but the impulse for the establishment of VPPs is technical innovations. They could be diffused only if some conditions are fulfiled, e.g.: the social adaptation, economic and financial efficiency, legal possibilities.

\section{Business models of VPP}

\subsection{Comparison of VPP's business models}

In search for the best BM that could be adopted in Polish conditions, a review of different BMs was carried out. The number of VPPs is still growing all over the world. But some of the VPPs used the same business models, which are duplicated in various localizations. In order to critically compare different BMs American, German, Finnish, Danish and Australian VPPs business models were taken into consideration (Table 1).

To make a critical comparison and to demonstrate a holistic view of business models six components were taken into account: strategy, resources, network, customers, value propositions, revenue. Strategy - the goal of foundation or creation of VPP. Resources - the type of DER and their number, total capacity, other resources such as software, human, financial. Network - key partners like energy utility (TSO, DSO), ISO, energy producers, commercials, industries, municipalities, gas suppliers and infrastructure owners. Consumers - it is a type of end-user (e.g. residential, commercial). Value proposition - a proposition of added value for owners and consumers (e.g. energy security, lower energy cost). Revenue the sources of revenue (e.g. typical services such as storage, energy reserve) and revenue streams.

The VPP's goals are usually connected with the national energy or environment policy goals such as being carbon neutral, reducing carbon footprint, decreasing negative influence on the climate, increasing the RES share or CHP share in electricity generation, ensuring energy security, improving grid resiliency, reliability and sustainability. Linking the VPP's 
goals with goals of national policy resulting in key partners which are local government, utility and energy companies, energy supplier, national energy agency. Such solutions require financial and legislative support from authorities.

Two different types of the DER's portfolio in VPP should be emphasized. In the first case, solid oxide fuel cells based m-CHP are used alone or with PV. Then, the key partner should be a gas supplier. In the second case different RES are connected together with energy storage systems. Among RES, predominately PVs are used, but also wind turbines, biogas generation. In one example of VPP, among energy storage systems, electric vehicle stations are used. In another case, instead of DERs, micro-grids are used. The total capacity of VPP differs significantly from less than $1 \mathrm{MW}$ to 4,583 MW.

Among the customers, to whom value proposition is addressed should be specified: residential customer, municipalities, commercial and industrial customers, energy storages, utility companies.

\subsection{A proposal for Polish VPP's business model}

In Polish conditions the value chain can be perceived from two points of view: customer's (large industry end-user) and electricity producer's (the owner of micro-installation). In the next research another types of consumers (prosumer, energy storages, energy clusters and energy cooperatives) will be analyzed.

In this section two types of customer segments such as large industry end-user and the owner of micro-installation, with particular value propositions and value chain are analysed. The components of the BM are presented in Table 2 . The following assumptions were made for VPP:

- resources - the DER portfolio is: PV installation, hydro power plant and energy storage system, IT platform and smart metering;

- key partners are: ISO, TSO, DSO and retail utility, telecommunication company;

- communication channels could be the direct phone calls and Internet contacts through the customer's panel;

- customer relationships will be realized by using free software and automated service or by a dedicated customer relationship manager.

For two types of customer segments like large industry end-user and the owner of microinstallation, varied value propositions, sources of revenue and key activities aiming to achieve value proposition were proposed.

\section{Conclusions}

By successfully combining business and technology innovations, the VPP has developed a pioneering business concept based on the powerful synergies between the existing energy market segments and the customers. The VPP is an IT structure which connects energy producers and consumers with each other and with other market segments in real time through a SG. The biggest challenge in SG are non-technical issues such as regulations, law, $\mathrm{BM}$, and the economic efficiency of investment.

BMs in the electric power sector are embedded in the regulatory and policy frameworks that characterize the sector. In wholesale electricity markets, market rules are established by a central authority and new DER business models selling services in wholesale electricity markets must conform to the market rules and regulations established by these authorities. All authorities could be stockholders in the BM and/or key partners. So, current DER business models are driven more by regulatory and policy factors than by technological factors. 
The economic and political aspects are the greatest obstacles to the development of the VPP in the energy sector in Poland. Another important barrier is a low level of RES development (the RES share in energy generation is about 14\%) and a low level of smart metering development. To develop VPPs in Poland local and national authorities and energy companies (TSO, DSO) should be involved.

The VPP gives positive effects on electricity grid like ensuring energy security, improving grid stability and reliability, optimizing the use of the of the energy resources lowering the load - demand response, using operational reserves, managing of peak demand. VPPs are expected to be important components of the new intelligent energy infrastructure.

\section{References}

1. C. Wendy, Value Creation from E-Business Models: Issues and Perspectives (Burlington, Oxford, 2004)

2. T. Saebi, L. Lien, N.J. Foss, Long Range Planning, 50, 567-581 (2017)

3. B. W. Wirtz, A. Pistoia, S. Ullrich, V. Gottel, Long Range Planning, 49, 36-54 (2016)

4. P. Timmers, Electronic Markets, 8 (2), 3-8 (1998)

5. P. Weill, M.R. Vitale, Place to Space - Migrating to e-Business Models (Harvard Business School Publishing, Boston, 2001)

6. A. Afuah, C.L. Tucci, Internet Business Models and Strategies (McGraw-Hill/Irwin, New York, 2003)

7. R. Amit, C. Zott, Strategic Management Journal, 22 (6/7), 493-520 (2001)

8. Baden-Fuller, Haefliger, Long Range Planning, 46, 419-426 (2013)

9. A. Osterwalder, Y. Pigneur, Business Model Generation (Wiley\&Sons, NJ, 2010)

10. G. Hamel, Leading the Revolution (Harvard Business School Press, Boston, 2000)

11. J. Magretta, Harvard Business Review, 80 (5), 86-92 (2002)

12. H. Chesbrough, R.S. Rosenbloom, Industrial and Corporate Change, 11 (3), 529-555 (2002)

13. D.J. Teece, Long Lange Planning, 43, 172-194 (2010)

14. S.M. Shafer, H.J. Smith, J. Linder, Business Horizons, 48 (3), 199-207 (2005)

15. K. Jacobsen, A Study of Virtual Organizations - in mobile computing environments (Norwegian University of Science and Technology, NTNU, 2004)

16. A. Mowshowitz, Systems Research and Behavioral Science, 14(6), 373-384 (1997)

17. P. Grajewski, A Process-Oriented Organisation (PWE, Warsaw, 2007)

18. J. van Aken, L. Hop, G.J.J. Post, Managing Strategically in an Interconnected World (Chichester, John Wiley \& Sons, 1998)

19. T.J. Strader, F. Lin, M.J. Shaw, Decision Support Systems, 23, 75-94 (1998)

20. U. Schultze, W.A. Orlikowski, Information and Organization, 11 (1), 45-77 (2001)

21. H.Walker, Int. J. Networking and Virtual Organisations, 3 (1), 25-41 (2006)

22. K. Zimniewicz, Contemporary concepts and methods of management (PWE, Warsaw, 2009)

23. J. Kisielnicki, MIS Management Information System (Placet, Warsaw, 2008)

24. P. Asmus, The Electricity Journal, 23, 10, 72-82 (2010)

25. J. Kumagai, IEEE Spectrum, 49 (3), 13-14, 2012

26. C. Ramsay, The Virtual Power Plant: Enabling Integration of distributed generation and demand (FENIX Bulletin, 2008)

27. T. Ackermann, G. Andersson, L. Söder, Electric Power Systems Research, 57, 195-204 (2001)

28. Ł. Nikonowicz, J. Milewski, Journal of Power Technologies, 92 (3), 135-49 (2012)

29. M. Loßner, D. Böttger, T. Bruckner, Energy Economics, 62, 125-138 (2017) 